\title{
A call for caution in extrapolating chest CT sensitivity for COVID-19 derived from hospital data to patients among general population
}

\author{
Yì Xiáng J. Wáng \\ Department of Imaging and Interventional Radiology, Faculty of Medicine, The Chinese University of Hong Kong, Shatin, New Territories, Hong \\ Kong, China \\ Correspondence to: Yî Xiáng J. Wáng. Department of Imaging and Interventional Radiology, Faculty of Medicine, The Chinese University of Hong \\ Kong, Shatin, New Territories, Hong Kong, China. Email: yixiang_wang@cuhk.edu.hk.
}

Submitted Feb 28, 2020. Accepted for publication Mar 05, 2020.

doi: 10.21037/qims.2020.03.04

View this article at: http://dx.doi.org/10.21037/qims.2020.03.04

I congratulate Ai et al. for their efforts in analysing a large cohort of corona virus disease 2019 (COVID-19) patients (1). Their results and insights will be helpful for the future in case similar scenario would occur again. However, we need also to re-emphasise the background where and when their data were collected. Their patient data were based in a tertiary hospital in Wuhan and during the period of Jan 6, 2020 to Feb 6, 2020. During this period in Wuhan the attention was mainly paid to the patients with more severe symptoms. While the clinical severity of the patients was not provided in Ai et al.'s paper, it is highly probable that a large proportion of their patients had moderate to severe grades severity.

The results from hospital-based patients usually do not represent the patients in general population, where the proportion of asymptomatic virus carrier and milder cases will be much larger. Patients during their latency period will also be CT negative but contagious. COVID-19 does not necessarily have pneumonia, thus the once-used-name of novel coronavirus pneumonia has been replaced with COVID-19. For milder cases, the chest CT positive rate will be much lower (2), and chest CT positive rate among asymptomatic COVID-19 patients remain unknown. For these cases, the role of biological pathogen testing can be more important.

As Ai et al. pointed out, their results may only be valid in epidemic areas with high pre-test probability for this disease (1). The current CT application for COVID-19 management in China is graphically shown in Figure S1.
When prevalence of COVID-19 is not higher than prevalence of other viral pneumonia, CT's specificity for COVID-19 will be another concern. These days in China we are talking of COVID-19's CT features have been increasingly atypical (personal communication with colleagues). Of note, lately the performance of biological testing for COVID-19 pathogen, including the introduction of 2019-nCoV IgM Detection Kit, has been markedly improved $(3,4)$. Moreover, due to its much lower radiation, serial chest radiograph can be used in the places of CT for monitoring disease regression or progression (5).

\section{Acknowledgments}

Funding: None.

\section{Footnote}

Conflicts of Interest: YXW serves as an unpaid Editor-inChief of Quantitative Imaging in Medicine and Surgery.

Open Access Statement: This is an Open Access article distributed in accordance with the Creative Commons Attribution-NonCommercial-NoDerivs 4.0 International License (CC BY-NC-ND 4.0), which permits the noncommercial replication and distribution of the article with the strict proviso that no changes or edits are made and the original work is properly cited (including links to both the formal publication through the relevant DOI and the license). 
See: https://creativecommons.org/licenses/by-nc-nd/4.0/.

\section{References}

1. Ai T, Yang Z, Hou H, Zhan C, Chen C, Lv W, Tao Q, Sun Z, Xia L. Correlation of Chest CT and RT-PCR Testing in Coronavirus Disease 2019 (COVID-19) in China: A Report of 1014 Cases. Radiology 2020. doi: 10.1148/ radiol.2020200642.

2. Xu R, Du M, Li L, Zhen Z, Wang H, Hu X. CT imaging of one extended family cluster of corona virus disease 2019 (COVID-19) including adolescent patients and "silent infection”. Quant Imaging Med Surg 2020;10:800-4.

3. To KK, Tsang OT, Chik-Yan Yip C, Chan KH, Wu TC, Chan JMC, Leung WS, Chik TS, Choi CY, Kandamby

Cite this article as: Wáng YXJ. A call for caution in extrapolating chest CT sensitivity for COVID-19 derived from hospital data to patients among general population. Quant Imaging Med Surg 2020;10(3):798-799. doi: 10.21037/ qims.2020.03.04
DH, Lung DC, Tam AR, Poon RW, Fung AY, Hung IF, Cheng VC, Chan JF, Yuen KY. Consistent detection of 2019 novel coronavirus in saliva. Clin Infect Dis 2020. doi: 10.1093/cid/ciaa149.

4. Available online: http://rs.yiigle.com/yufabiao/1182686. htm. Accessed March 1, 2020.

5. Holshue ML, DeBolt C, Lindquist S, Lofy KH, Wiesman J, Bruce H, Spitters C, Ericson K, Wilkerson S, Tural A, Diaz G, Cohn A, Fox L, Patel A, Gerber SI, Kim L, Tong S, Lu X, Lindstrom S, Pallansch MA, Weldon WC, Biggs HM, Uyeki TM, Pillai SK; Washington State 2019-nCoV Case Investigation Team. First Case of 2019 Novel Coronavirus in the United States. N Engl J Med 2020;382:929-36. 


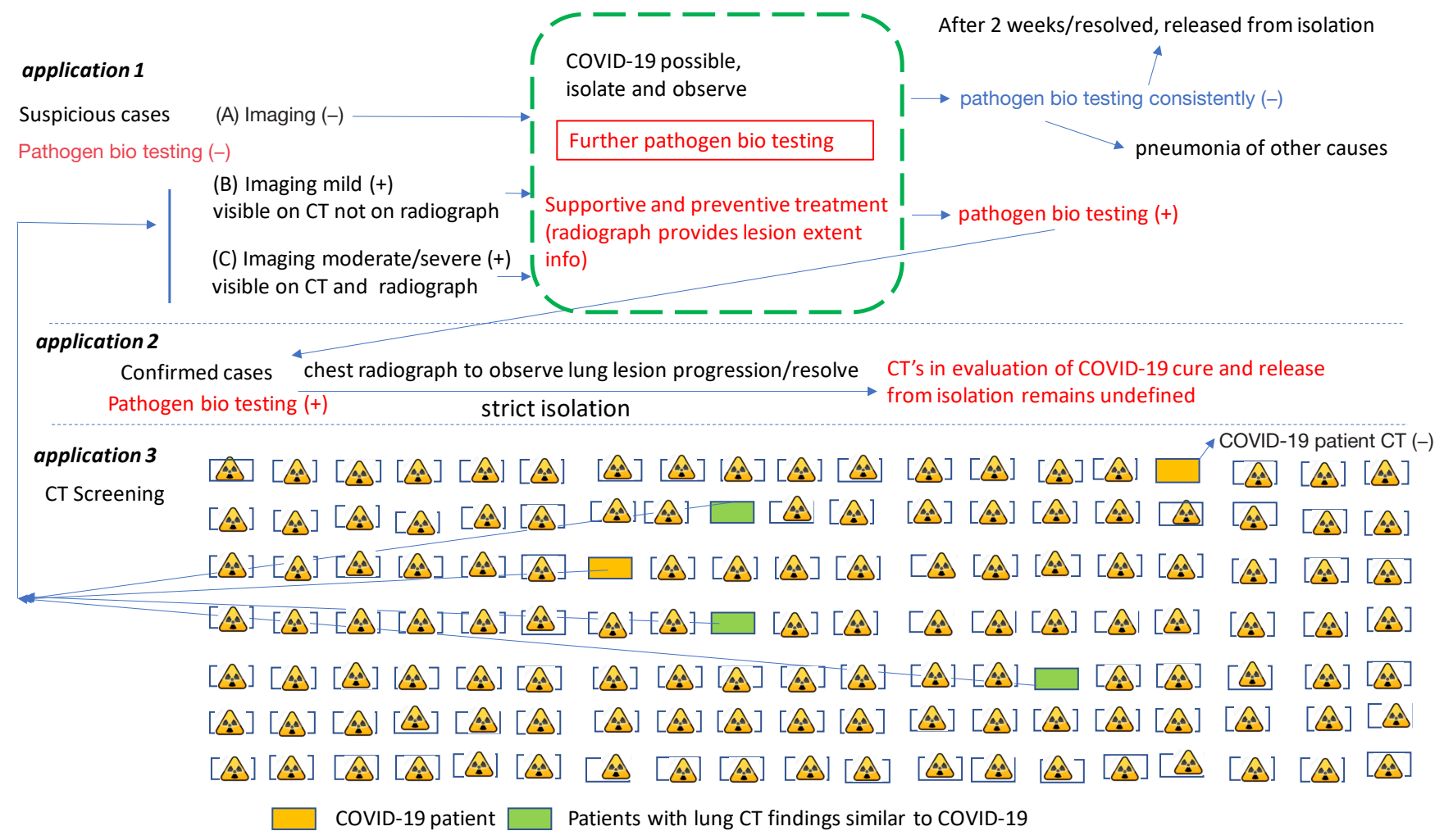

Figure S1 A diagram of current CT applications for COVID-19 management in China. In some published studies, chest CT studies' limitations have not been explained in detail by the original authors and have not been carefully scrutinized by readers, this has led to a substantial increase of chest CTs. In application-1, it can be seen that if appropriate protocols are followed, then the clinical management for cases in (A) and cases in (B) would be the same. In application-3, chest CT's role in COVID management will be limited by CT's sensitivity and low prevalence of COVID-19 in the targeted population (estimated to be $0.77 \%$ in Wuhan general population, with majority of mild severity; the prevalence is much lower in other parts of China). Note in application-3, due to limited space, the normal cases are vastly under-represented in this graph. 